\title{
Purification and characterization of a novel plant lectin from Pinellia ternata with antineoplastic activity
}

\author{
Zhenyu Zuo ${ }^{1}$, Handong Fan ${ }^{2}$, Xue Wang ${ }^{2}$, Wei Zhou ${ }^{1}$ and Lingling $\mathrm{Li}^{1}$
}

\begin{abstract}
A novel Pinellia ternata lectin was purified from the bulbs of a Chinese herb Pinellia ternata using a combination of hydrophobic chromatography and DEAE-ion exchange chromatography. The lectin was found to be a homodimer of 12093.3 Da subunits as determined by gel filtration and MS. Biochemical characterization of the lectin revealed the existence of a glycoprotein, which contains 3.22\% neutral sugars. The N-terminal 10-amino acid sequence of the lectin, QGVNISGQVK, has not been reported for other lectins. The lectin had a special agglutinating activity with mouse erythrocytes at a minimum concentration of $8.0 \mathrm{ug} / \mathrm{ml}$. The lectin was stable in the $\mathrm{pH}$ range of pH 5-12 and temperatures up to $80^{\circ} \mathrm{C}$ for $30 \mathrm{~min}$. The results of $\mathrm{MTT}$ experiment showed that the lectin had significant effect towards tumor cells, the maximum inhibition of cell proliferation with Sarcoma 180, HeLa and K562 cell line were $85.2 \%, 74.6 \%$ and $59.4 \%$ respectively. Experimental therapy in vivo also showed that PTL apparently inhibited transplanted tumor in mice. Flow cytometric analysis demonstrated that PTL inhibited the proliferation of Sarcoma 180 in a time- and dose-dependent manner through inhibiting the transition of $G_{1} / S$ and subsequently inducing $\mathrm{G}_{0} / \mathrm{G}_{1}$ cell cycle arrest. Thus, Pinellia ternata lectin displays a high potential for antitumor activity.
\end{abstract}

Keywords: Lectin, Pinellia ternata, Antineoplastic activity, Purification

\section{Background}

Lectins are carbohydrate-binding proteins of nonimmune origin with the ability to recognize special sugars existing on cell surfaces as a result of cell agglutination (Peumans and Van Damme 1998). They are ubiquitous occurred in microorganisms, plants and animals and have attracted great interest due to their varied physiological roles in cell agglutination (Khan et al. 2007), anti-tumor (Liu et al. 2009, 2010), immunomodulatory (Rubinstein et al. 2004), antifungal (Herre et al. 2004) and antiviral effects (Wong and Ng 2005). Plant lectins have been extensively used for the detection, segregation and description of glycoconjugates using their carbohydrate binding properties (Peumans and Van Damme 1998). In recent years, lectins are used to trigger vesicular transport into or across epithelial cells and

\footnotetext{
* Correspondence: fanhandong@whu.edu.cn

Institute of Microbiology, Jiangxi Academy of Sciences, Jiangxi 330029, China

Full list of author information is available at the end of the article
}

used in food security management and diagnosis of disease. Furthermore, lectin-mediated drugs have been acquired to target specific cells and some lectins with anti-proliferative properties were isolated and characterized from different parts of the plant like seeds (Lin and $\mathrm{Ng}$ 2008), leaves (Park et al. 1997) and roots (Yan et al. 2010).

Pinellia ternata is a traditional Chinese medicine which was used for the treatment of insomnia, eclampsia and termination of pregnancy for hundreds of years under the name of Banxia. It has been studied by many researchers due to the important discovery in the clinical application that the aqueous extract of Pinellia ternata contributed to the treatment of cervical carcinoma by smearing on the afflicted part (Lin et al. 2003). Much research (Luo et al. 2000; Chen et al. 2003; Wu et al. 2011) has been done on indigenous compounds like polysaccharide, astragaloside, isoflavonoids, triterpene, saponins and various trace elements in Pinellas radix. However, not much information is available regarding the bioactive proteins from this herb. Some researchers insisted 
that sitosterol was the constituent; however, Sun et al. found that the total proteins obviously inhibited ovarian cancer cell lines but showed no toxicity to human umbilical cord blood hematopoietic progenitor's in vitro (Sun et al. 1992; Zhu et al. 1999). Fu et al. also found that the $30 \%\left(\mathrm{NH}_{4}\right)_{2} \mathrm{SO}_{4}$ deposition part of total proteins from Pinellia ternata rhizome could significantly inhibit human hepatocellular carcinoma cell line Bel-7402 growth and induce its apoptosis (Fu et al. 2007). Therefore, we could easily speculate that the lectin in total proteins of Pinellia Ternata may be one of the effective constituents with anti-tumor activity. But to date, there are no reports about the bioactive proteins from Pinellia ternata with anti-tumor activity.

A novel lectin with hemagglutinating activity was purified from the bulbs of Pinellia Ternata using a combination of hydrophobic chromatography and DEAE-ion exchange chromatography and characterized for its antineoplastic property in the present work.

\section{Results \\ Purification of lectin}

A lectin from Pinellia ternata was purified by a combination of ion exchange and hydrophobic chromatographic steps, which revealed strong agglutination activity with KM mouse erythrocytes. Hemagglutinating activity test was employed to monitor all the purification procedure. Fractionation of crude extract by precipitation with ammonium sulphate was dialysed against $20 \mathrm{mM}$ Tris- $\mathrm{HCl}$ ( $\mathrm{pH}$ 7.4) and loaded onto a PHE Sepharose Cl-4B column. Then active fraction was pooled and applied to DEAE-sepharose chromatography. A gradually enriched lectin with the agglutinating activity was purified and then was designated as Pinellia ternata lectin (PTL) (Figure 1A). A summary of its purification was provided in Table 1.

\section{Properties of purified lectin}

The physical and biochemical properties of the lectin were investigated. The molecular mass of PTL was estimated to be $12.1 \mathrm{kDa}$ using SDS-polyacrylamide gel electrophoresis (SDS-PAGE) (Figure 1A) or $25.8 \mathrm{kDa}$ using gel filtration on the Sephacryl S-100 (Figure 1B). The mass spectrometry analysis appeared as a peak corresponding to $\mathrm{m} / \mathrm{z} 12093.30 \mathrm{Da}$ (Figure 1C). These results indicated that PTL is a homodimer consisting of two identical subunits of 12093.30 Da. Carbohydrate analysis using the phenol-sulfuric acid assay revealed that PTL was a glycoprotein with a neutral carbohydrate content of $3.22 \%$ (data not shown). Amino acid composition analysis of PTL indicated that Asp, Val, Glu, Ser, and Lys were present in higher concentrations than other amino acids (Table 2). The first $10 \mathrm{~N}$-terminal amino acid sequence of PTL was determined as QGVNISGQVK.

\section{Effect of temperature and $\mathrm{pH}$}

Thermal stability of PTL was determined in the temperature range from $20^{\circ} \mathrm{C}$ to $95^{\circ} \mathrm{C}$. The results indicated that PTL was fairly stable up to $80^{\circ} \mathrm{C}$ for $30 \mathrm{~min}$. However, the activity decreased significantly at higher temperatures and was totally inactivated when incubated at $95^{\circ} \mathrm{C}$ for $30 \mathrm{~min}$ (Figure $2 \mathrm{~A}$ ). The $\mathrm{pH}$ sensitivity profile of the lectin is shown in (Figure 2B). PTL exhibited broad pH optima between $\mathrm{pH} 5$ and $\mathrm{pH}$ 12, but its activity was completely lost at $\mathrm{pH}$ below 3 .

\section{The antitumor activity of PTL in vitro}

The anti-proliferative property of PTL against Sarcoma 180 cell line, Human cervical carcinoma cell line (HeLa) and human leukaemia K562 cell line are shown in (Figure 3). The maximum inhibitory effect of PTL on proliferation of Sarcoma 180, HeLa and K562 cell lines were observed with $40 \mu \mathrm{g} / \mathrm{ml}$ concentration for $48 \mathrm{~h}$ treatment. The maximum inhibition of cell proliferation with Sarcoma 180, HeLa and K562 cell lines were 85.2\%, 74.6\% and 59.4\% respectively. Besides, the inhibition ratio for PTL in the above tested cell lines showed a concentration-dependence and time-dependence patterns. The results indicated that PTL showed maximum inhibition with Sarcoma 180 cells as compared to HeLa cells and K562 cells.

\section{The antitumor activity of PTL in vivo}

PTL was intraperitoneal injected into Kunming mice with different concentrations and Cyclophosphamide (CTX) was used here as positive control to assess the antineoplastic effect of PTL on tumor growth. CTX is the most commonly used positive control in anti-cancer drug screening experiments and also the major chemotherapy drugs for cancer clinical treatment. Mice bearing Sarcoma 180 tumor exhibited a significantly $(\mathrm{p}<0.005)$ lighter tumor weight after PTL injection compared with the control mice, while animals injected with CTX showed a significantly lighter tumor body weight compared with the mice injected with PTL (Table 3). The inhibition rate were $15.6 \%, 32.1 \%, 36.2 \%$ according to the concentration of PTL $(0.85 \mathrm{mg} / \mathrm{kg}, 2.30 \mathrm{mg} / \mathrm{kg}, 3.25 \mathrm{mg} / \mathrm{kg}$ ) respectively. The results showed that PTL was an effective inhibitor toward tumor in vivo even though its effect was not as good as CTX.

\section{Flow cytometry (FCM) analysis}

Aiming to elucidate the mechanism of inhibiting transplanted tumor in mice, the ability of PTL to inhibit cell cycle progression was analyzed by FCM. A representative example depicting the effect of PTL treatment for 


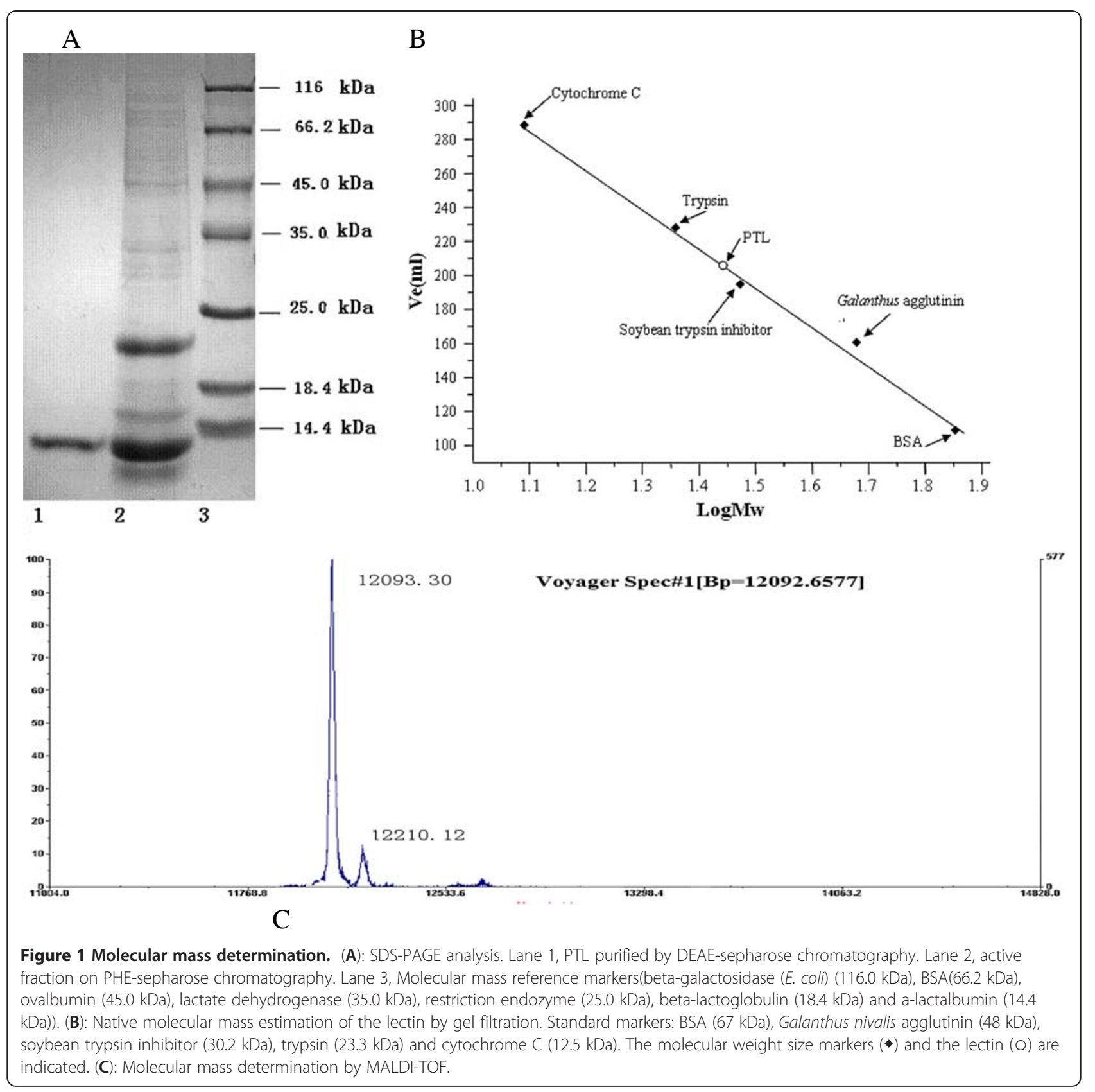

Table 1 Specific hemagglutinating activities and yields of chromatographic fractions obtained at different steps of purification of lectin

\begin{tabular}{cccccc}
\hline Fraction & $\begin{array}{c}\text { Total } \\
\text { protein(mg) }\end{array}$ & $\begin{array}{c}\text { Specific hemagglutinating } \\
\text { activity (HA/mg) }\end{array}$ & $\begin{array}{c}\text { Total activity } \\
\text { by HA }\end{array}$ & $\begin{array}{c}\text { Purification } \\
\text { fold }\end{array}$ & $\begin{array}{c}\text { Recovery of } \\
\text { protein (\%) }\end{array}$ \\
\hline Crude extract & 2600 & 8.75 & 22750 & 1 & 100 \\
hydrophobic chromatography & 235 & 65.83 & 15470 & 7.5 & 9.04 \\
ion-exchange chromatography & 74 & 125.41 & 9280 & 14.3 & 2.85 \\
\hline
\end{tabular}

Purification was initiated from $100 \mathrm{~g}$ of bulbs of Pinellia ternata, a lectin from Pinellia ternata was purified by a combination of ion exchange and hydrophobic chromatographic steps, which revealed strong agglutination activity with Kunming mouse erythrocytes. Hemagglutinating activity test was employed to monitor all the purification procedure. The total activity was measured by hemagglutinating activity assay as described in "materials and methods" section. 
Table 2 Amino acid composition of the lectin from the bulbs of Pinellia ternata

\begin{tabular}{cccccc}
\hline Amino acid & Mol (\%) & Amino acid & Mol (\%) & Amino acid & Mol (\%) \\
\hline Asp & 14.17 & Val & 12.50 & Glu & 11.67 \\
Ser & 10.00 & Lys & 8.33 & Leu & 6.67 \\
Gly & 5.83 & Thr & 5.00 & Ala & 5.00 \\
Gln & 4.17 & His & 3.33 & Arg & 3.33 \\
Lle & 2.50 & Asn & 1.67 & Pro & 1.67 \\
Met & 1.67 & Cys-s & 0.83 & Phe & 0.83 \\
Tyr & 0.83 & Trp & 0 & & \\
\hline
\end{tabular}

$12 \mathrm{~h}$ or $24 \mathrm{~h}$ on cell cycle phase distribution in the Sarcoma 180 cells is shown in (Figure 4). Treatment with 5, 20 and $40 \mu \mathrm{g} / \mathrm{ml}$ of PTL for $12 \mathrm{~h}$ or $24 \mathrm{~h}$ resulted in a significant decrease in the $S$ DNA but little change in the $G_{2} / M$ DNA. As expected, no apoptosis was observed, which was in accordance with the results of MTT experiments. The decrease in the S DNA accompanied by the increase in the $G_{0} / G_{1}$ DNA was an indication of the inhibition of DNA replication, which might have taken place during the $G_{1} / S$ transition phase.

\section{Discussion}

Pinellia ternata is one kind of traditional Chinese medicinal plant species, belonging to family Araceae. So far, majority of research reports concerning Pinellia ternate are around the aqueous extract and indigenous compounds of Pinellia ternata. Purification and characterization of one lectin with antitumor activity from Pinellia ternata have not been previously reported. Previous insect bioassay studies showed that Pinellia ternata agglutinin (PTA) from P.ternata had significant insecticidal activities. Yao et al. cloned the full-length cDNA of PTA with molecular weight about 29.4KD (Yao et al. 2003). Wu et al. cloned another gene of Pinellia ternata agglutinin named as PTA-1, which encoded a lectin protein of 269 amino acids but had the similar molecular weight as PTA (Wu et al. 2010). In the present study, PTL is a homodimer consisting of two identical subunits of 12093.30 Da, which is significantly different from PTA and PTA-1. In the present study, a novel lectin with obvious antitumor activity has been purified from Pinellia ternata bulbs for the first time using conventional chromatographic methods. The final yield of PTL is merely $2.85 \%$ after the procedure of hydrophobic chromatography and DEAE-ion exchange chromatography, approximately $740 \mathrm{mg}$ lectin per kilogram dried material. PTL was found to be a homodimer with a molecular mass of $25.8 \mathrm{kDa}$. The lectin was a glycoprotein as detected by periodic staining. PTL was found to contain $3.22 \%$ of neutral sugars. In addition, PTL exhibited no sequence similarity with other previously reported lectins according to the search results from $\mathrm{N}$-terminal homology, MALDI-TOF MS/MS analysis and database. Thus, PTL might be a novel araceae lectin, which has not been reported in any lectin family.

PTL, characterized by high thermostability and $\mathrm{pH}$ stability, exhibited agglutination towards Kunming mouse erythrocytes with the minimum agglutinating concentration of PTL $8 \mu \mathrm{g} / \mathrm{ml}$. While lectin retained its full hemagglutinating activity up to $80^{\circ} \mathrm{C}$ for $30 \mathrm{~min}$, PTL retained its full hemagglutinating activity in the broad $\mathrm{pH}$ range of $\mathrm{pH} 5$ to 12 . In addition, the activities of some other lectins are diminished above $\mathrm{pH} 9$ reportedly (kaur et al. 2005; Suseelan et al. 2007; Vaz et al. 2010).

Recently, the excellent antineoplastic activity of plant lectins has driven more and more attention to cancer

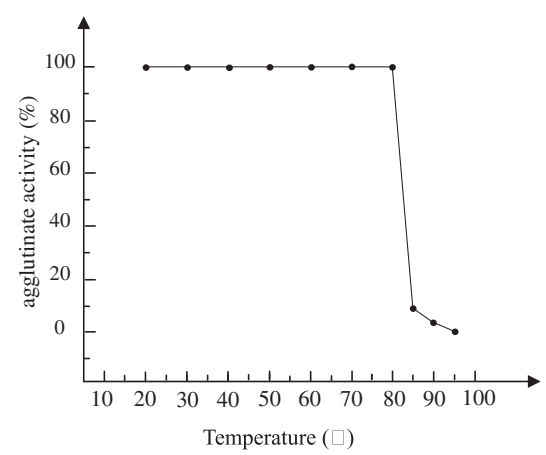

(A)

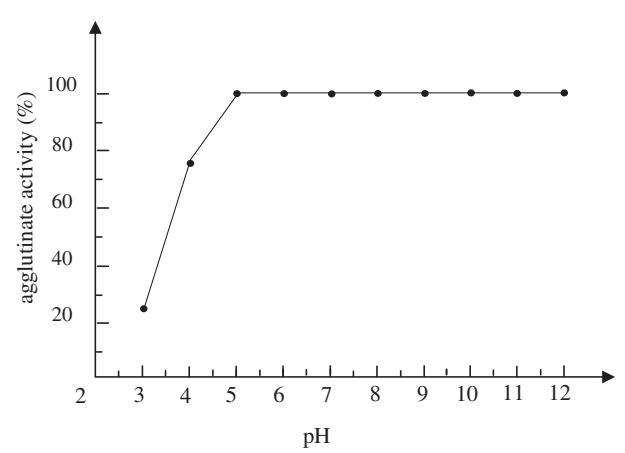

(B)

Figure 2 Thermal stability and pH stability of PTL on the agglutinating activity were performed as described in "materials and methods" section. (A): PTL was incubated at various temperatures for $30 \mathrm{~min}$ then rapidly cooled on ice. The residual hemagglutination activity was tested at room temperature. The hemagglutination activity of an untreated sample, tested at room temperature, represented $100 \%$ activity. (B): PTL was incubated at room temperature $\left(24^{\circ} \mathrm{C}\right)$ in $20 \mathrm{mg} / \mathrm{ml}$ of different $\mathrm{pH}$ buffers ranging from $\mathrm{pH} 3$ to 12 . The titer value obtained at $\mathrm{pH}$ 8.0 represented $100 \%$ activity. 


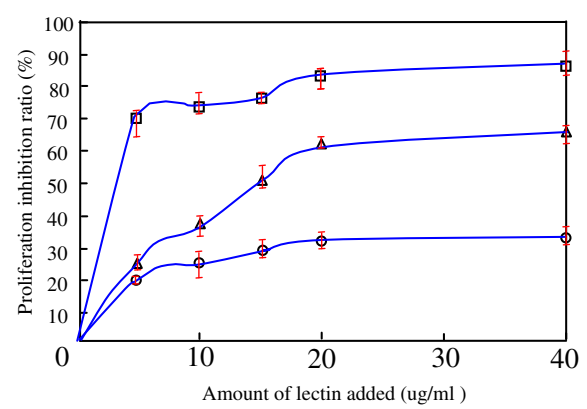

(A)

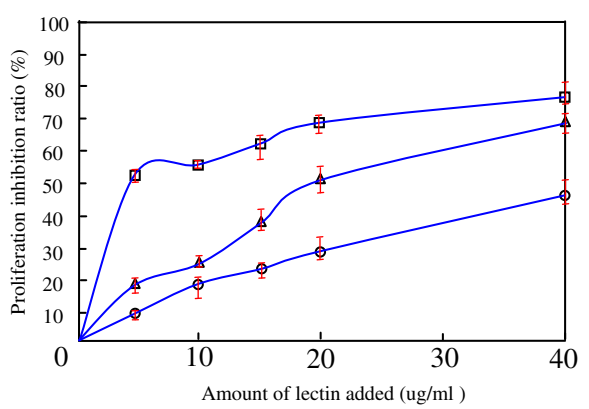

(B)

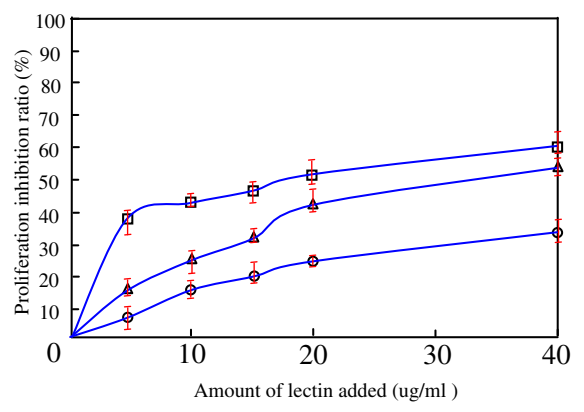

(C)

Figure 3 Anti-proliferative effect of PTL on Sarcoma 180 cell line (A), HeLa cell line (B) and K562 cell line(C) were performed as described in "materials and methods" section. Each data is expressed as the mean \pm SD obtained from triplicate experiments. Symbols: $12 \mathrm{~h}$ $(0), 24 h(\Delta), 48 \mathrm{~h}(\square)$. Untreated cells were used for comparative purposes in this experiment and the Proliferation inhibition ratio was calculated according to the equation "materials and methods" section.

studies (Jung et al. 2007). Numerous studies have reported that some "ideal" anti-cancer candidate drugs can induce apoptosis in susceptible cancer cells (Nicholson 2000). Like these anti-cancer drugs, PTL executed dose-dependent growth-inhibitory effect on three typical cancer cells. Sarcoma 180, HeLa and K562 cell lines showed growth-inhibitory responses to PTL by MTT assay. Moreover, further study about the anti-tumor activity of PTL in vivo has been performed in Kunming mice. The results showed that PTL apparently inhibited Sarcoma180 and transplanted tumor in mice, but the inhibition mechanism of PTL affecting proliferation and growth is still unknown. Is it PTL itself that transported to the tumor to initiate a biological response? Or does PTL in the intraperitoneal cavity cause the release of factors that via the blood are taken up by the tumor? Further in-depth research was needed to answer these questions.

In order to further investigate the mechanism of inhibiting transplanted tumor in mice by either inducing apoptosis or inhibiting cell proliferation, the effect of PTL on cell cycle progression was analyzed by FCM. The results suggested that PTL could cause a significant decrease of S phase in Sarcoma180, which indicated that the inhibition of cell growth was due to the arrest of DNA replication in the cell cycle. Thus the blockage

Table 3 Effect of PTL on growth of sarcoma 180 in mice

\begin{tabular}{cccr}
\hline & Dose $* \mathbf{m g} / \mathbf{k g})$ & Tumor weight $\mathbf{( g )}$ & Inhibitory rate $*(\%)$ \\
\hline CTX & 20.00 & $0.463 \pm 0.180$ & $68.3 \pm 12.2$ \\
PTL & 3.25 & $0.935 \pm 0.160$ & $36.2 \pm 10.9$ \\
& 2.30 & $0.995 \pm 0.131$ & $32.1 \pm 8.9$ \\
Negative control $(0.9 \% \mathrm{NaCl})$ & 0.85 & $1.236 \pm 0.132$ & $15.6 \pm 9.0$ \\
\hline
\end{tabular}

The anti-tumoral effect was determined by examining the tumor weight and calculating the inhibition rate as described below. The value of $P$ ( $p<0.005$ ) was calculated according to the tumor weight at every experiment group.

※Each dose was tested in 12 mice every other day for 10 days;

*Inhibitory rate $=[$ (tumor weight of control mice-tumor weight of experimental mice)/tumor weight of control mice $] \times 100 \%$. 


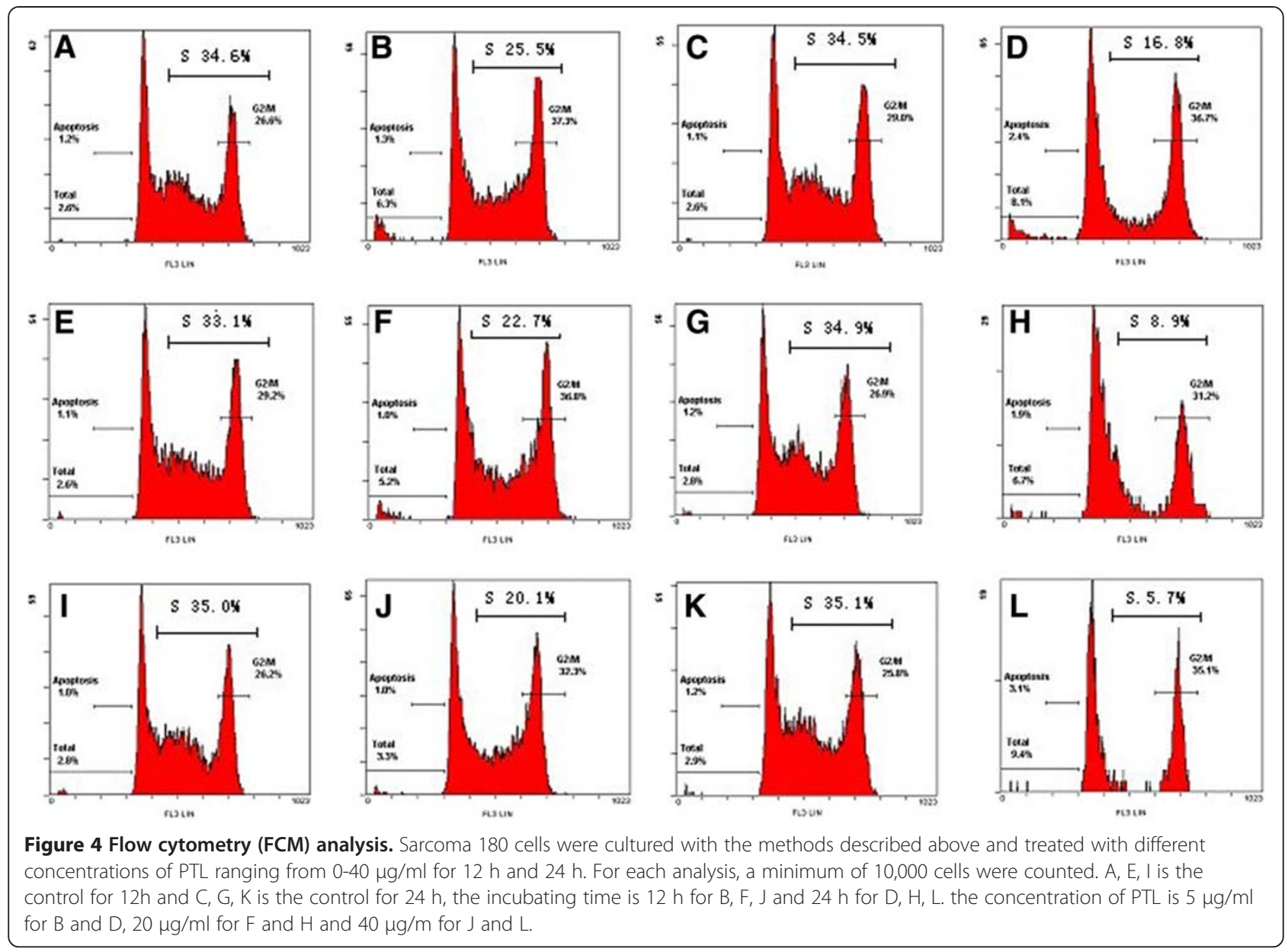

effect of PTL occurred at $G_{1} / S$ transitions, correspondingly, the number of cells in $G_{1} / G_{0}$ phase increased and the number of cells in $\mathrm{S}$ phase decreased. In fact, a great number of studies have been reported that the arrest of cells at the checkpoints of the cell cycle occurs as an event happens preceding the detection of apoptotic cells (Balzarini et al. 2004; Surh 1999).

In summary, we purified PTL from The bulbs of Pinellia ternata and characterized some notable biological characteristics, especially its antineoplastic activity, for the first time. Due to accumulating evidence, the findings of PTL and many other plant lectins reported (Liu et al. 2009; Yan et al. 2009) would start a new exploration for plant lectins as potential anti-cancer candidate drugs due to their potentially remarkable antineoplastic activity. Furthermore, it might provide more promising insights into pharmaceutical exploitation in treatment of different human diseases in the near future.

\section{Materials and methods \\ Materials}

The Pinellia ternata purchased from Jinmen Hubei province had been identified for its authenticity by Keli
Chen in Chinese Medicine of Hubei College of traditional Chinese Medicine; PHE Sepharose Cl-4B and DEAE Sepharose Fast Flow were purchased from Amersham Pharmacia Biotech; Roswell Park Memorial Institute 1640 (RPMI 1640) was from HyClone (USA); CTX was purchased from Wuhan University Zhongnan Hospital; MTT (3-(4,5-dimethylthiazol-2-yl)-2,5diphenyltetrazolium bromide) and Dulbecco's Modified Eagle's Medium (DMEM) were products of SinoAmerican Biotechnology Company. Kunming Mice were purchased from Laboratory Animal Center of School of Medicine in Wuhan University and the experiments in vivo were performed in the same center. Mice blood was obtained by puncturing the marginal ear veins of healthy animals. The Sarcoma 180 and Hela cells were obtained from China Center for Typical Culture Collection. All other chemicals used were analytical grade reagents unless otherwise mentioned.

\section{Extraction and purification of lectin from the bulbs of Pinellia ternata}

The bulbs of Pinellia ternata (100 g) were homogenized for $30 \mathrm{~s}$ at the internal interval of $1 \mathrm{~min}$ in deionized 
water at $4^{\circ} \mathrm{C}$ for $4 \mathrm{~h}$. The extract was centrifuged at $8000 \mathrm{rpm}$ for $40 \mathrm{~min}$. The resultant pellet was discarded and the proteins in the supernatant were brought to $40 \%$ saturation of ammonium sulphate by stirring slowly, cooled at $4^{\circ} \mathrm{C}$ overnight and then centrifuged at $8000 \mathrm{rpm}$ for $40 \mathrm{~min}$. The precipitate was dissolved in $20 \mathrm{mM}$ Tris- $\mathrm{HCl}$ buffer ( $\mathrm{pH}$ 7.4) and dialyzed against the same buffer containing $1.5 \mathrm{M}$ ammonium sulphate. After $16 \mathrm{~h}$ of dialysis, the sample was applied onto PHE Sepharose Cl-4B column which had been preequilibrated with "Tris- $\mathrm{HCl}$ buffer" mentioned above. Elution was carried out with the gradient buffer from "Tris- $\mathrm{HCl}$ buffer" containing $1.5 \mathrm{M}$ ammonium sulphate to "Tris- $\mathrm{HCl}$ buffer" containing $0 \mathrm{M}$ ammonium sulphate and monitored at $280 \mathrm{~nm}$. The fractions exhibiting hemagglutinating activity were collected, dialysed against "Tris- $\mathrm{HCl}$ buffer" and then concentrated by centricon (PM-3). The concentrated active parts were loaded to a DEAE-Sepharose Fast Flow column (25 $\mathrm{mm} \times 160 \mathrm{~mm})$, which had been pre-equilibrated with "Tris- $\mathrm{HCl}$ buffer". The bound protein was eluted by a continuous linear gradient of "Tris- $\mathrm{HCl}$ buffer" containing 0-0.3 $\mathrm{M} \mathrm{NaCl}$. The fractions exhibiting hemagglutinating activity were pooled and used for further studies. The purified lectin was designated as PTL.

\section{Protein concentration assay, hemagglutination assay and carbohydrate analysis}

We measured the soluble protein content with the Bradford assay (Bradford 1976) using bovine serum albumin as a standard. Hemagglutinating activity was measured in V-well microtitre plates (Cao et al. 2010). A total volume of $0.1 \mathrm{ml}$ was used in each well: $10 \mu \mathrm{l}$ aliquots of serial three-fold dilutions of PTL in PBS, $20 \mu \mathrm{l}$ of $2 \%$ suspension of mice erythrocytes in PBS and $70 \mu \mathrm{l}$ of PBS were incubated for $2-3 \mathrm{~h}$ at room temperature and titre of visible agglutination by eye-sight was noted. One hemagglutination unit is defined as the lowest concentration of lectin that causes visible erythrocyte agglutination. The positive and the negative control were Concanavalin A and PBS respectively. Carbohydrate content of the purified lectin was determined by the phenol sulphuric acid method as described by the Dubois method using D-glucose as a standard (Dubois et al. 1956).

\section{Homogeneity and molecular mass determination}

SDS-PAGE was performed using $12.5 \%(\mathrm{w} / \mathrm{v})$ acrylamide in gels, the molecular weight standard was the low molecular weight markers: beta-galactosidase ( $E$. coli) $(116.0 \mathrm{kDa})$, BSA $(66.2 \mathrm{kDa})$, ovalbumin $(45.0 \mathrm{kDa})$, lactate dehydrogenase $(35.0 \mathrm{kDa})$, restriction endozyme $(25.0 \mathrm{kDa})$, beta-lactoglobulin $(18.4 \mathrm{kDa})$ and alactalbumin $(14.4 \mathrm{kDa})$.
Native molecular mass of the purified lectin was detected by Sephacryl S-100 column $(2.0 \mathrm{~cm} \times 75 \mathrm{~cm})$ which had been pre-equilibrated with $20 \mathrm{mM}$ PBS (pH 7.4). Elution was carried out with the same buffer at a flow rate of $0.4 \mathrm{ml} / \mathrm{min}$ and monitored at $280 \mathrm{~nm}$. The molecular mass of the eluting lectin was estimated from a plot of the log of the molecular weight, while a distribution coefficient (Kav) was calculated from the elution volume of the standard markers. The molecular mass standards used for calibration were BSA $(66.2 \mathrm{kDa})$, Galanthus nivalis agglutinin $(48 \mathrm{kDa})$, soybean trypsin inhibitor $(30.2 \mathrm{kDa})$, trypsin $(23.3 \mathrm{kDa})$ and cytochrome $\mathrm{C}(12.5 \mathrm{kDa})$.

Mass spectra were performed by using a Voyager-DESTR MALDI-TOF mass spectrometer. The samples were pooled and redissolved in water containing $0.1 \%$ trifluoroacetic acid for desalting with $\mathrm{C} 18$ ziptips before being analyzed with MS.

\section{Amino acid composition and $\mathrm{N}$-terminal determination}

The lectin was hydrolyzed with $6 \mathrm{M} \mathrm{HCl}$ at $100^{\circ} \mathrm{C}$ for $30 \mathrm{~h}$. The hydrolyzate residue in the supernatant was quickly derivatized with 9-fluorenylmethoxycarbonyl chloride and O-phthalaldehyde. The amino acid derivatives were analyzed by using HPLC with a Hypersil ODS C18 $(4.6 \mathrm{~mm} \times 150 \mathrm{~mm})$ column. The N-terminal aa sequence analysis was performed by using an Applied Biosystems protein sequencer through automated Edman degradation.

\section{Temperature and $\mathrm{pH}$ profile}

To study $\mathrm{pH}$ stability of the lectin, purified lectin was incubated at room temperature $\left(24^{\circ} \mathrm{C}\right)$ in $20 \mathrm{mg} / \mathrm{ml}$ of different $\mathrm{pH}$ buffers ranging from $\mathrm{pH} 3$ to 12 : $\mathrm{NaH}_{2} \mathrm{PO}_{4}$-citric acid buffer ( $\mathrm{pH}$ 3.0-5.5), sodium phosphate buffer ( $\mathrm{pH}$ 6.0-7.5), Tris- $\mathrm{HCl}$ buffer ( $\mathrm{pH}$ 8.0-9.0) and glycine- $\mathrm{NaOH}$ buffer ( $\mathrm{pH}$ 9.5-12). After incubation for $30 \mathrm{~min}$, the residual hemagglutinating activity was calculated.

To study the effect of temperature on hemagglutinating activity, purified lectin was incubated for $30 \mathrm{~min}$ at $20,30,40,50,60,70,80,85,90$ and $95^{\circ} \mathrm{C}$ in PBS (pH 7.4). After incubation, aliquots were rapidly cooled on ice and the residual hemagglutinating activity was checked. The results were expressed as percentage of residual activity relative to the control.

\section{MTT colorimetric assay}

Sarcoma 180 cell line, Human cervical carcinoma cell line (HeLa) and human leukaemia K562 cell line were used in the MTT colorimetric assay. Culturing and maintenance of these cells were followed as Yan (Yan et al. 2009) and cell proliferation was checked by an MTT assay. Cells $\left(1 \times 10^{5}\right)$ in their exponential growth 
phase were seeded into each well $(200 \mu \mathrm{l}$ media per well) of a 96 well plate and incubated at $37^{\circ} \mathrm{C}$ in a $5 \% \mathrm{CO}_{2}$ incubator. After $12 \mathrm{~h}$ (the cell density was about $80 \%$ ), cell culture were removed and new culture was added, different concentrations of PTL (pre-sterilised with $0.22 \mu \mathrm{m}$ film filtration) ranging from $0-40 \mu \mathrm{g} / \mathrm{ml}$ were added to the well and the cells were further grown at $37^{\circ} \mathrm{C}$ for $48 \mathrm{~h}$. After removing the supernatant, $200 \mu \mathrm{l}$ of PBS containing $5 \mathrm{mg} / \mathrm{ml} \mathrm{MTT}$ was added and incubated at $37^{\circ} \mathrm{C}$ for $4 \mathrm{~h}$. The supernatant was removed again and $150 \mu \mathrm{l}$ of dimethyl sulphoxide was added into each well to dissolve the MTT formazan at the bottom of the wells. After $10 \mathrm{~min}$, the absorbance was read at $492 \mathrm{~nm}$ using enzymelinked immunosorbent assay plate reader. The proliferation inhibition ratio was calculated using the following equation: Proliferation inhibition ratio $(\%)=[(\mathrm{U}-\mathrm{T}) / \mathrm{U}] \times 100 \%$; where, $\mathrm{U}$ is the $\mathrm{OD}_{492} \mathrm{~nm}$ of the cells without PTL treatment (control) and $\mathrm{T}$ is the $\mathrm{OD}_{492} \mathrm{~nm}$ of the cells with PTL treatment. All experiments were carried out in triplicate.

\section{Establishment of sarcoma 180 tumors and experimental therapy in vivo}

Sarcoma 180 cells were inoculated subcutaneously into male Kunming strain mice to establish tumors and this animal model of tumor was used to determine the antineoplastic effect of PTL on tumor growth. Kunming mouse has been widely used in medical experiments for its adaption to a variety of experimental environment. Sarcoma 180 cells, which were suspended in normal saline solution at $2.5 \times 10^{6} \mathrm{cells} / \mathrm{ml}$, were implanted subcutaneously on right front leg armpit (Kuznetsova et al. 1999). Each mouse received $0.2 \mathrm{ml}$ mixture of tumor suspension subcutaneously. After $24 \mathrm{~h}$, PTL was maintained at the different concentrations ranging from $0-3.25 \mathrm{mg} / \mathrm{kg}$ body weight for intraperitoneal injection at every other day. CTX was given at $20 \mathrm{mg} / \mathrm{kg}$ body weight to the positive control group and $0.2 \mathrm{ml}$ PBS solution was given to the negative control group. On the 11th day, after the mice were sacrificed, tumors and spleens indexes were extirpated and weighed. Later, the inhibition ratio of the tumors and the organ indexes were calculated as described by Chen (Chen et al. 2003).

\section{Flow cytometry analysis}

Sarcoma 180 cells were cultured with the methods described above and treated with different concentrations of PTL ranging from $0-40 \mu \mathrm{g} / \mathrm{ml}$ for $12 \mathrm{~h}$ and $24 \mathrm{~h}$. The cells were processed by trypsin, collected and washed twice with ice-cold PBS, and then suspended in $75 \%$ ethanol at $-20^{\circ} \mathrm{C}$ overnight. Fixed cells were centrifuged at $600 \mathrm{~g}$ for $5 \mathrm{~min}$ and washed with ice-cold PBS again. To study the DNA content and the cell cycle, cells were incubated with $100 \mu \mathrm{g} / \mathrm{ml}$ RNase A in PBS at $37^{\circ} \mathrm{C}$ for $1 \mathrm{~h}$ before stained in the dark with PI $(20 \mu \mathrm{g} / \mathrm{ml})$ at $4^{\circ} \mathrm{C}$ for $30 \mathrm{~min}$. Samples were applied to a flow cytometer. For each analysis, a minimum of 10,000 cells were counted.

\section{Abbreviations}

PTL: Pinellia ternata lectin; SDS-PAGE: SDS-polyacrylamide gel electrophoresis; CTX: Cyclophosphamide; FCM: Flow cytometry; PTA: Pinellia ternata agglutinin; RPMI 1640: Roswell Park Memorial Institute 1640;

DMEM: Dulbecco's Modified Eagle's Medium; MTT: 3-(4,5-dimethylthiazol-2yl)-2,5-diphenyltetrazolium bromide.

\section{Competing interests}

The authors declare that they have no competing interests.

\section{Authors' contributions}

Zuo ZY and Fan HD have contributed to the experimental conception and design, to the acquisition of data, to the analysis and interpretation of data. they have also been involved in drafting and revising the manuscript. Zuo ZY has performed all the experiments carried out about purification and characterization of PTL. Fan HD has performed mainly the experiments carried out about antineoplastic activity of PTL. Zhou W and Li LL have contributed to the acquisition of data and helped with the development of the experiments about purification and characterization of PTL. Wang X has contributed to the acquisition of data and helped with the development of the experiments about antineoplastic activity of PTL. Furthermore, Wang X, Zhou $\mathrm{W}$ and Li LL have been involved in critically revising the manuscript and for important intellectual content. All authors read and approved the final manuscript.

\section{Purpose of the work}

Some researchers found that the total proteins of Pinellia ternata obviously inhibited ovarian cancer cell lines and we want to verify the lectin in total proteins of Pinellia ternata is one of the effective constituents with antitumor activity in this work.

\section{Acknowledgements}

This work was supported in part by Key Technology R\&D Program of Jiangxi Province (2009BNA06600, 2008BC34400, 2010BNA08000), Jiangxi Academy of Sciences National Pre-research project(2010-2012)and Youth Pre-research project of Wuhan University of Science and Technology(2008-2010).

\section{Author details}

${ }^{1}$ College of Chemical Engineering and Technology, Wuhan University of Science and Technology, Wuhan 430081, China. ${ }^{2}$ Institute of Microbiology, Jiangxi Academy of Sciences, Jiangxi 330029, China.

Received: 2 May 2012 Accepted: 7 August 2012

Published: 16 August 2012

\section{References}

Balzarini J, Laethem KV, Hatse S, Vermeire K, Clercq ED, Peumans W, Van Damme E, Vandamme AM, Bolmstedt A, Schols D (2004) Profile of resistance of human immunodeficiency virus to mannose-specific plant lectins. J Virol 78:10617-10627

Bradford MM (1976) A rapid and sensitive method for the quantitation of microgram quantities of protein utilizing the principle of protein-dye binding. Anal Biochem 72:248-254

Cao X, Sun Y, Wang C, Zeng B (2010) Purification and characterization of a new D-galactose-specific lectin from the housefly, Musca domestica, and its antiproliferative effect on human K562 and MCF-7 tumor cells. J Insect Sci 10:79-82

Chen JH, Cui GY, Liu JY, Tan RX (2003) Pinelloside, an antimicrobial cerebroside from Pinellia ternate. Phytochemistry 64:903-906

Dubois M, Gilles KA, Hamilton JK, Rebers PA, Smith F (1956) Colorimetric method for determination of sugars and related substances. Anal Chem 28:350-356

Fu Y, Li J (2007) Extraction and isolation of the protein groups with anti-tumor activity from Pinellia ternata. Chinese J Inform TCM 14:45-46

Herre J, Willment JA, Gordon S, Brown GD (2004) The role of Dectin-1 in antifungal immunity. Crit Rev Immunol 24:193-203

Jung EC, Kim KD, Bae CH, Kim JC, Kim DK, Kim HH (2007) A mushroom lectin from ascomycete Cordyceps militaris. Biochim Biophys Acta 1770:833-838 
Kaur A, Singh J, Kamboj SS, Sexana AK, Pandita RM, Shamnugavel M (2005) Isolation of an $\mathrm{N}$-acetyl-D-glucosamine specific lectin from the rhizomes of Arundo donax with antiproliferative activity. Phytochemistry 66(16):1933-1940

Khan F, Ahmad A, Khan Ml (2007) Purification and characterization of a lectin from endophytic fungus Fusarium solani having complex sugar specificity. Arch Biochem Biophys 457:243-251

Kuznetsova IM, Yakusheva TA, Turoverov KK (1999) Contribution of separate tryptophan residues to intrinsic fluorescence of actin. Analysis of 3D structure. FEBS Lett 452:205-210

Lin J, Yao J, Zhou X, Sun X, Tang K (2003) Expression and purification of a novel mannose-binding lectin from Pinellia ternata. Mol Biotechnol 25:215-222

Lin P, Ng TB (2008) Preparation and biological properties of a melibiose binding lectin from Bauhinia variegata seeds. J Agr Food Chem 56(22):10481-10486

Liu B, Zhang B, Min MW, Bian HJ, Chen LF, Liu Q, Bao JK (2009) Induction of apoptosis by Polygonatum odoratum lectin and its molecular mechanisms in murine fibrosarcoma L929 cells. Biochim Biophys Acta 1790(8):840-844

Liu B, Bian HJ, Bao JK (2010) Plant lectins: potential antineoplastic drugs from bench to clinic. Cancer Lett 287(1):1-12

Luo L, Wang JN, Kong LD, Jiang QG, Tan RX (2000) Antidepressant effects of Banxia Houpu decoction, a traditional Chinese medicinal empirical formula. J Ethnopharmacol 73:277-281

Nicholson DW (2000) From bench to clinic with apoptosis-based therapeutic agents. Nature 407:810-816

Park WB, Han SK, Lee MH, Han KH (1997) Isolation and characterization of lectins from stem and leaves of Korean mistletoe (Viscum album var. coloratum) by affinity chromatography. Arch Pharm Res 20(4):306-312

Peumans WJ, Van Damme EJM (1998) Plant lectins versatile proteins with important perspectives in biotechnology. Biotechnol Genet Eng Rev 15:199-228

Rubinstein N, llarregui JM, Toscano MA, Rabinovich GA (2004) The role of galectins in the initiation, amplification and resolution of the inflammatory response. Tissue Antigens 64:1-12

Sun GX, Ding S, Qian YJ (1992) The extraction and chemical analysis of proteins from Pinellia pedatisecta and their inhibitory effects on the mouse Sarcoma180. J Shanghai Med 19:17-20

Surh YJ (1999) Molecular mechanisms of chemopreventive effects of selected dietary and medicinal phenolic substances. Mutat Res 428:305-327

Suseelan KN, Bhagwath A, Pandey R, Gopalkrishna T (2007) Characterization of ConA, a lectin from Canavalia cathartica Thouars seeds. Food Chem 104:528-535

Vaz AFM, Costa RMPB, Melo AMMA, Oliva MLV, Santana LA, Silva-Lucca RA, Coelho LCBB, Correia MTS (2010) Biocontrol of Fusarium species by a novel lectin with low ecotoxicity isolated from Sebastiania jacobinensis. Food Chem 119(4):1507-1513

Wong JH, Ng TB (2005) Isolation and characterization of a glucose/mannose/ rhamnose-specific lectin from the knife bean Canavalia gladiata. Arch Biochem Biophys 439:91-98

Wu XY, Zhao JL, Zhang M, Li F, Zhao T, Yang LQ (2011) Sedative, hypnotic and anticonvulsant activities of the ethanol fraction from Rhizoma Pinelliae Praeparatum. J Ethnopharmacol 135:325-329

Wu ZM, Dong WQ, Dang ZH, Pan WL, Xie XL, Wen CX, Chen JF (2010) The gene cloning of Pinellia ternata agglutinin and its resistance to peach aphids (Myzus persicae). J nanjing Agri Univ 33:45-50

Yan QJ, Li YX, Jiang ZQ, Yan S, Zhu LF, Ding ZF (2009) Antiproliferation and apoptosis of human tumor cell lines by a lectin (AMML) of Astragalus mongholicus. Phytomedicine 16:586-593

Yan QJ, Zhu LF, Kumar N, Jiang ZQ, Huang LH (2010) Characterisation of a novel monomeric lectin (AML) from Astragalus membranaceus with antiproliferative activity. Food Chem 122:589-595

Yao JH, Zhao XY, Liao ZH, Lin J, Chen ZH, Chen F, Song J, Sun XF, Tang KX (2003) Cloning and molecular characterization of a novel lectin gene from Pinellia ternate. Cell Res 13:301-308

Zhu MW, Zheng K, Ding SS (1999) Total proteins of pinellia pedatisecta effects in ovarian cancer cell lines and in human umbilical cord blood hematopoietic progenitors. J Shanghai Med 26:455-458

doi:10.1186/2193-1801-1-13

Cite this article as: Zuo et al:: Purification and characterization of a novel plant lectin from Pinellia ternata with antineoplastic activity. SpringerPlus 2012 1:13.

\section{Submit your manuscript to a SpringerOpen ${ }^{\circ}$ journal and benefit from:}

- Convenient online submission

- Rigorous peer review

- Immediate publication on acceptance

- Open access: articles freely available online

- High visibility within the field

- Retaining the copyright to your article

Submit your next manuscript at $>$ springeropen.com 